\title{
Pengaruh Gross Motoric Training terhadap Kemampuan Koordinasi Motorik pada Anak Developmental Coordination Disorder di SLBN Surakarta
}

\author{
Prasaja $^{1^{*}}$ \\ ${ }^{1}$ Prodi D III Okupasi Terapi Politeknik Kesehatan Kemenkes Surakarta \\ *Email: prasajaahmad@gmail.com
}

Kata Kunci
Gross Motoric
Training,
Kemampuan
Koordinasi
Motorik,
Developmental
Coordination
Disorder
(DCD)

\begin{abstract}
Abstrak
Developmental Coordination Disorder (DCD) adalah istilah yang digunakan untuk menggambarkan kesulitan dalam pengembangan keterampilan gerak, adanya keterlambatan perkembangan pada motor skills, kesulitan dalam belajar atau melakukan keterampilan yang membutuhkan koordinasi motorik. Aktivitas gross motor sangat penting untuk menstimuli pertumbuhan dan perkembangan pada anak-anak dengan DCD. Penelitian ini bertujuan untuk mengetahui pengaruh aktivitas gross motoric training terhadap kemampuan koordinasi motorik pada anak Developmental Coordination Disorder di SLBN Surakarta. Desain penelitian ini adalah quantitative pre-experimental design tipe one-group pretest-posttest. Peneliti menggunakan teknik purpossive sampling atau jugmental sampling. Sampel berjumlah 33 orang terdiri dari 28 laki-laki dan 5 perempuan. Alat pengumpul data berupa tes menggunakan instrument Test of Gross Motor Development-2. Metode analisis data yang digunakan dengan teknik statistik uji t-test berpasangan. Hasil Penelitian ini antara lain golongan umur sebagian besar sampel berada pada rentangan usia 6.00-6.11 tahun $(39,4 \%)$, berdasarkan jenis kelamin didominasi oleh laki-laki $(84,8 \%)$, menurut diagnosis sebagian besar Autism (48.5\%). Ada pengaruh positif, dan signifikan secara statistik dari intervensi aktivitas gross motoric training terhadap kemampuan koordinasi motorik pada anak Developmental Coordination Disorder ( $p=0,001)$. Kesimpulan penelitian ini adalah gross motoric training berpengaruh positif terhadap kemampuan koordinasi motorik pada anak Developmental Coordination Disorder.
\end{abstract}

\section{The Effect of Gross Motoric Training on Motor Coordination Capability in Children with Developmental Coordination Disorder at SLBN Surakarta}

\begin{abstract}
Key Words:
Abstract

Gross motoric

Developmental Coordination Disorder (DCD) is a term used to describe difficulties

Training,

Motor in the development of motion skills, developmental delay in motor skills, difficulty in

Coordination

Ability,

Developmental learning or performing skills requiring motor coordination. Gross motor activity is very importance to stimulate growth and development in children with DCD. The purpose of this study was to determine the effect of gross motoric training activity on

Coordination motor coordination ability in children with Developmental Coordination Disorder at

Disorder SLBN Surakarta. This study was a quantitative pre-experimental design of one-group

$(D C D)$ pretest-posttest type. A sample of 33 study subjects consisting 28 male and 5 female was selected by purpossive sampling or jugmental sampling. The data were collected by test with Test of Gross Motor Development-2 instrument. The Data were analyzed by paired t-test. Research result was age-group outcomes were predominantly 6.006.11 years (39.4\%), based on sex dominated by males (84.8\%), according to the diagnosis of most children diagnosed with Autism (48.5\%). There were positive, and statistically significant effects of intervention gross motoric training on motor coordination capability in children with Developmental Coordination Disorder ( $p=$ 0.001). Conclusion this research was gross motoric training affected on motor coordination ability in children with Developmental Coordination Disorder.
\end{abstract}


PROFESI (Profesional Islam): Media Publikasi Penelitian

2019; Volume 16; No 2.

Website: ejournal.stikespku.ac.id

\section{PENDAHULUAN}

Developmental Coordination Disorder $(D C D)$ adalah istilah yang digunakan untuk menggambarkan kesulitan dalam pengembangan keterampilan gerak, adanya keterlambatan perkembangan pada motor skills (Wood et al., 2017), kesulitan dalam belajar atau melakukan keterampilan yang membutuhkan koordinasi motorik (Vareka et al., 2017). Kondisi ini mempengaruhi kinerja tugas sehari-hari anak baik di lingkungan rumah, bermain dan sekolah (Kirby \& Sugden, 2007; Henn et al., 2003; Missiuna et al., 2011).

Dampak klinis pada $D C D$ tergantung pada penyebab gangguan, berat-ringannya gangguan, keterampilan motorik yang terdampak dan pengaruh lingkungan (pola asuh). Beberapa penelitian menunjukkan bahwa anak $D C D$ mempunyai defisit pada keterampilan motorik kasar dan halus, kontrol postural, dan propioseptif dengan hambatan motorik pada kesulitan gerakan anggota gerak atas dan bawah (Missiuna et al., 2011). Gerakan terkoordinasi dianggap sebagai pemetaan persepsi (input) terhadap kemampuan motorik / tindakan (output). Hal ini membutuhkan pengolahan informasi di empat lokasi yaitu sensorik dan persepsi, pengambilan keputusan dan perencanaan, eksekusi gerakan, serta umpan balik. Defisit dalam satu atau lebih komponen ini dapat mengakibatkan koordinasi motorik yang buruk (Wilson \& Crawford, 2007).

Anak-anak dengan diagnosis $D C D$ menggunakan lebih banyak aktivitas menggunakan otot di sekitar pinggul dan bahu dibandingkan anakanak normal dengan usia yang sama (Kaiser, 2013). Mereka menggunakan 'strategi fiksasi' persendian selama aktivitas yang mengharuskan menstabilkan satu sendi atau bagian tubuh sehingga bagian lain dapat dipindahkan dengan kontrol yang lebih baik, sehingga hal ini menyebabkan gerakan menjadi kaku dan kikuk ( Missiuna et al., 2011). Pada penelitian sebelumnya telah menunjukkan pentingnya aktivitas fisik untuk menstimuli pertumbuhan dan perkembangan pada anak-anak dengan $D C D$ dan bahwa tanpa intervensi untuk memperbaiki keterampilan motorik maka aktivitas fisik dan aktivitas seharihari tidak akan membaik (Adams \& Steenbergen, 2017). Terdapat berbagai permasalahan pada penderita $D C D$ untuk dapat beraktivitas fungsional. Seringkali anak-anak $D C D$ mendapatkan nilai buruk di sekolah, memiliki stabilitas tubuh dan daya tahan yang buruk dengan tugas motorik kasar seperti melempar dan menangkap bola, belajar dan melakukan banyak tugas baru (Campbell \& Missiuna, 2012). Hal ini menyebabkan anak tidak berpartisipasi dalam kegiatan sekolah dan kurang termotivasi untuk berinteraksi secara sosial, sebagai konsekuensinya anak memiliki kepercayaan diri yang rendah (Costini et al., 2017) serta menarik diri dari aktivitas sosial (Rivilis et al., 2011).

Beberapa hasil penelitian menyatakan bahwa hambatan yang dialami anak $D C D$ dalam melakukan koordinasi gerak motorik dapat diperbaiki dengan aktivitas gross motoric training (Blaisdell, 2015; Henn et al., 2003). Di dalam gross motoric training terdapat komponen-komponen dasar gross motor skills yang melibatkan kelompok otot besar pada tubuh digunakan untuk menjalankan fungsi seperti menjaga keseimbangan yang akan mengembangkan komponen gross motor menjadi lebih kompleks, dimana kemampuan tersebut dibutuhkan untuk mengorganisasikan dan mengkoordinasi kan lengan, kaki dan mata dalam melakukan aktivitas seharihari (Bridgend, 2008). Penelitian ini bertujuan menginvestigasi pengaruh aktivitas gross motoric training terhadap kemampuan koordinasi motorik pada anak Developmental Coordination Disorder di SLBN Surakarta.

\section{METODE PENELITIAN}

Penelitian ini adalah quantitative preexperimental design tipe one-group pretestposttest. Peneliti melakukan pengukuran untuk menentukan anak memiliki gangguan $D C D$ atau tidak, serta melakukan pengukuran terkait kemampuan gross motor pada anak. Penentuan gangguan DCD menggunakan Developmental Coordination Disorder Questionnairre 2007 (DCDQ'07), sedangkan pengukuran gross motor menggunakan Test of Gross Motor Development2 (TGMD-2).

Sampel dalam penelitian ini adalah sebagian dari murid SLBN Surakarta yang telah dilakukan assessment mengalami $D C D$ memiliki hambatan gerak karena kemampuan gross motor. Peneliti menggunakan teknik purpossive sampling atau jugmental sampling, dimana peneliti memilih subjek berdasarkan kriteria spesifik yang ditetapkan sebelumnya. Sampel diambil dengan kriteria 
inklusi sebagai berikut: (1) Anak mengalami keterlambatan gerak motorik (2) Anak kooperatif (3) Anak tidak mengalami gangguan komunikasi (4) Anak mampu memahami instruksi (5) Anak tidak mengalami gangguan neuromuscular (misalnya: distrofia musculorum progressive, cerebral palsy). Instrumen yang digunakan dalam penelitian ini ada dua instrumen yaitu Developmental Coordination Disorder Questionnairre 2007 (DCDQ'07) (Wilson, 2007), digunakan untuk melakukan assessment dalam menentukan diagnosis apakah anak mengalami $D C D$ atau tidak. Sedangkan instrumen Test of Gross Motor Development second edition (TGMD-2) (Ulrich, 2000), digunakan untuk menilai kemampuan koordinasi motorik anak.

\section{HASIL DAN PEMBAHASAN \\ Hasil Penelitian}

Karakteristik subyek penelitian pada penelitian ini meliputi distribusi umur, jenis kelamin dan kondisi subyek penelitian. Deskripsi karakteristik subyek penelitian tertera pada tabel 1 .

Tabel 1. Karakteristik Subyek Penelitian

\begin{tabular}{llcc}
\hline Subyek & Rentang & $\begin{array}{c}\text { Frekuensi } \\
(\mathrm{n}=33)\end{array}$ & $\begin{array}{c}\text { Prosentase } \\
(\mathrm{n}=100 \%)\end{array}$ \\
\hline Umur & $5.0-5.11$ th & 3 & 9.1 \\
& $6.0-6.11$ th & 13 & 39.4 \\
& $7.0-7.11$ th & 6 & 18.2 \\
& $8.0-8.11$ th & 6 & 18.2 \\
& $9.0-9.11$ th & 5 & 15.2 \\
Sex & Perempuan & 5 & 15.2 \\
& Laki-laki & 28 & 84.8 \\
Diagnosis Down Syndrome & 9 & 27.3 \\
& Autism & 16 & 48.5 \\
& Developt Delay & 1 & 3.0 \\
& ADHD & 1 & 3.0 \\
& Mental Retardasi & 6 & 18.2 \\
\hline Sumber: Olah data SPSS versi $17(2017)$ &
\end{tabular}

Tabel 1. menunjukkan gambaran demografi subyek penelitian, berdasarkan kelompok umur responden terbanyak pada rentang usia $6.0-6.11$ tahun berjumlah 13 subyek (39.4\%), jenis kelamin didominasi oleh laki - laki berjumlah 28 subyek (84.8\%), dan kondisi terbanyak Autism berjumlah 16 subyek (48.5\%).
Uji prasyarat dilakukan untuk mengetahui apakah data berdistribusi normal. Untuk menentukan uji statistik yang akan digunakan terlebih dahulu dilakukan uji normalitas data hasil test sebelum dan sesudah intervensi. Uji normalitas menggunakan Uji Shapiro-Wilk test, hasilnya tertera pada tabel 2 .

Tabel 2. Hasil Uji Normalitas Data Skor

TGMD-2 Sebelum dan Sesudah Intervensi

\begin{tabular}{lc}
\hline Kelompok & p Uji Shapiro Wilk Test) \\
\hline Pre test TGMD-2 & 0.877 \\
Post test TGMD-2 & 0.983 \\
\hline
\end{tabular}

Sumber: Olah data SPSS versi 17 (2017)

Hasil dari uji normalitas data (Shapiro-Wilk test) sebelum dan sesudah intervensi memiliki nilai $\mathrm{p}>0.05$, yang berarti data skor $T G M D-2$ sebelum dan sesudah intervensi berdistribusi normal, sehingga memenuhi syarat untuk dilakukan uji parametrik (t-test berpasangan).

Untuk menguji hipotesis apakah terdapat pengaruh penerapan aktivitas gross motoric training terhadap kemampuan koordinasi motorik pada anak Developmental Coordination Disorder, maka dilakukan uji hipotesis.Oleh karena hasil uji normalitas data baik pada kelom-pok sebelum maupun sesudah intervensi berdistribusi normal, maka untuk mengetahui perbedaan rerata kemampuan koordinasi motorik menggunakan uji parametrik dengan paired sample t-test (uji t sampel berpasangan). Hasil uji $\mathrm{t}$ sampel berpasangan tertera pada tabel 3 .

Tabel 3. Uji Hipotesis Perbedaan Rerata Skor TGMD-2

\begin{tabular}{llllll}
\hline Kel & $\mathrm{n}$ & Rerata & SB & \multicolumn{3}{c}{ Uji paired t-test } \\
& & & & $\mathrm{t}$ & $\mathrm{p}$ \\
\hline Sebelum & 33 & 33.39 & 5.262 & -11.043 & 0.001 \\
Sesudah & 33 & 37.24 & 5.426 & & \\
\hline
\end{tabular}

Sumber: Olah data SPSS versi 17 (2017)

Tabel 3. menunjukkan beda rerata skor TGMD-2 antara sebelum dan sesudah intervensi yang dilakukan paired sample t-test dengan hasil $\mathrm{p}=0.001(<0.05)$. Hasil nilai tersebut mempunyai arti bahwa ada perbedaan rerata skor TGMD-2 secara bermakna antara sebelum dan sesudah 
PROFESI (Profesional Islam): Media Publikasi Penelitian

2019; Volume 16; No 2.

Website: ejournal.stikespku.ac.id

intervensi gross motoric training. Apabila dikaitkan dengan hipotesis penelitian berarti ada pengaruh gross motoric training terhadap kemampuan koordinasi motorik antara sebelum dan sesudah intervensi pada anak Developmental Coordination Disorder.

\section{Pembahasan}

Penelitian ini dilaksanakan di Klinik SLB Negeri Surakarta Jl. RM Said No. 111 Punggawan, Banjarsari, Surakarta, Jawa Tengah, merupakan klinik komunitas anak berkebutuhan khusus.

Berdasarkan penggolongan umur menunjukkan sebagian besar berada pada rentangan usia 6.00-6.11 tahun (39,4\%), hasil ini seiring dengan Data Kementerian Pendidikan dan Kebudayaan menunjukkan bahwa populasi penduduk usia sekolah di Indonesia pada tahun 2015 sebagian besar pada usia 0.00 - 6.00 tahun berjumlah 33.517.600, sedangkan paling sedikit pada usia 16.00 - 18.00 tahun berjumlah 13.281.300 jiwa. Faktor yang mempengaruhi kemampuan koordinasi motorik adalah kematangan usia anak dimana hal tersebut akan memberikan kesempatan kepada anak untuk belajar Semakin muda usia anak, maka pengalaman belajar pada anak kurang banyak dibandingkan dengan yang lebih tua sehingga kemampuan motorik anakpun juga tidak bisa sebaik anak yang lebih tua (Harris et al., 2015).

Berdasarkan jenis kelamin, didominasi oleh laki-laki (84,8\%). Jenis kelamin merupakan salah satu faktor internal yang dapat mempengaruhi perkembangan koordinasi motorik anak (Hurlock, 2014). Kemampuan anak perempuan dalam mengontrol gerakan tubuh dan koordinasi sedikit lebih baik dibandingkan dengan anak laki-laki. Hal ini dikarenakan karena anak perempuan dalam melakukan suatu aktivitas memiliki sifat tekun jika dibandingkan anak laki-laki, namun perbedaan ini berkurang perlahan seiring dengan bertambahnya usia (Harianti, 2003 dalam Ofianti, 2011).

Menurut diagnosis gangguan $D C D$, sebagian besar anak $D C D$ dengan diagnosis Autisme $(48,5 \%)$. Hal ini sesuai dengan penelitian Safaria, 2005 dalam Mufadhilah (2014), bahwa pada anak Autisme mengalami gangguan perkembangan pervasif secara menyeluruh mengganggu fungsi kognitif, emosi, dan psikomotorik anak. Sedang- kan menurut Veskarisyanti (2008) dalam Assjari, (2011), menyatakan bahwa anak penyandang Autisme mengalami gangguan pada perkembangan motorik, otot kurang kuat untuk berjalan, serta keseimbangan tubuhnya kurang baik.

Berdasarkan hasil uji statistik paired sample t-test menunjukkan hasil beda rerata skor TGMD2 antara sebelum dan sesudah intervensi didapat nilai $\mathrm{p}=0.001(<0.05)$. Hasil nilai tersebut mempunyai arti bahwa ada perbedaan rerata skor TGMD-2 secara bermakna antara sebelum dan sesudah intervensi gross motoric training. Apabila dikaitkan dengan hipotesis penelitian berarti ada pengaruh gross motoric training terhadap kemampuan koordinasi motorik antara sebelum dan sesudah intervensi pada anak dengan Developmental Coordination Disorder. Implikasi klinis dari pelatihan motorik dalam perannya untuk memperbaiki kemampuan koordinasi motorik seperti yang dijelaskan oleh Qian Yu (2014), bahwa dopamine adalah salah satu neuromodulator paling kuat yang dikeluarkan otak mamalia dalam mengatur fungsi sirkuit dan plastisitas. Ia memainkan peranan penting dalam mengendalikan gerakan, motivasi, gairah, kognisi dan reward sehingga meningkatkan minat dan konsentrasi dalam beraktivitas. Penelitian selama dekade terakhir telah meningkatkan pemahaman tentang plastisitas otak, yaitu bagaimana sirkuitsirkuit neuronal dapat dimodifikasi berdasarkan pengalaman baru yang dilatihkan kembali, pemberian obat-obatan, serta pembelajaran dalam perannya memperbaiki lesi di otak (Kolb et al., 2017). Plastisitas kortikal difahami sebagai tanggapan terhadap berbagai manipulasi eksperimental dari training yang terprogram. Dopamin merupakan modulator kunci plastisitas dalam sirkuit kortikostriatal, sangat terlibat dalam keterampilan motorik saat belajar pengalaman baru (Pawlak \& Jason, 2008).

Dalam penelitian lainnya, koordinasi motorik dibutuhkan dalam aktivitas sehari-hari seperti berjalan, mengetik, mengambil gelas, dan sebagainya sehingga gangguan koordinasi motorik dapat mempengaruhi kualitas hidup seseorang (Wuang et al., 2012).

Terdapat berbagai permasalahan pada penderita $D C D$ untuk dapat beraktivitas fungsional. Seringkali anak-anak $D C D$ mendapatkan nilai buruk di sekolah, memiliki stabilitas tubuh dan daya tahan yang buruk dengan tugas motorik 
PROFESI (Profesional Islam): Media Publikasi Penelitian 2019; Volume 16; No 2. Website: ejournal.stikespku.ac.id

kasar seperti melempar dan menangkap bola, belajar dan melakukan banyak tugas baru (Campbell \& Missiuna, 2012). Hal ini menyebabkan anak tidak berpartisipasi dalam kegiatan sekolah dan kurang termotivasi untuk berinteraksi secara sosial, sebagai konsekuensinya anak memiliki kepercayaan diri yang rendah (Costini et al, 2017) serta menarik diri dari aktivitas sosial (Rivilis et al., 2011).

\section{SIMPULAN}

Berdasarkan hasil analisis terhadap hasil intervensi terapi dengan metode yang telah direncanakan, dapat disimpulkan bahwa gross motoric training dapat meningkatkan kemampuan koordinasi motorik pada anak Developmental Coordination Disorder yang dilakukan 10 kali terapi. Autisme merupakan kondisi terbanyak dari diagnosis $D C D$, umur responden terbanyak pada rentang usia 6,0-6,11 tahun, jenis kelamin didominasi oleh laki - laki. Kemampuan koordinasi motorik kasar diperlukan anak untuk memperkuat otot kaki dan tangan, melatih konsentrasi, meningkatkan sosialitas anak, meningkatkan sensifitas dan meningkatkan kemampuan koordinasi anak.

\section{REFERENSI}

Adams I.L.J., Steenbergen B. (2017). Feasibility of Motor Imagery Training for Children with Developmental Coordination Disorder. Journal frontiers in Psychology 8:1271.

Assjari. (2011). Pengaruh Senam Fantasi Terhadap Kemampuan Motorik Kasar Anak Autis di SDN Inklusi Tebel Gedangan. Jurnalmahasiswa.unesa.ac.id. index.php/jurnal-pendidikan.

Blaisdell A.P. (2015). Play as the Foundation of Human Intelligence: The Illuminating Role of Human Brain Evolution and Development and Implications for Education and Child Development. Journal of Evolution and Health Volume 1 Issue 1.

Bridgend. (2008). Do and discover. Retrieved from http: //learning. gov. wales/docs/ learningwales/publications/130212doand-discoveren.pdf.
Campbell W. N \& Missiuna C. (2012). Peer Victimization and Depression in Children with and without Motor Coordination Difficulties. Psychology in the Schools. 49(4). Wiley Periodicals, Inc. DOI: 10.1002/pits.21600

Costini O, Roy A, Remigereau C, Faure S, Fossoud C and Le Gall D. (2017). Nature and Specificity of Gestural Disorder in Children with Developmental Coordination Disorder: A Multiple Case Study. Front. Psychol. 8:995. The journal Frontiers in Psychology July 2017. 8. Article 995.

Harris S. R., Mickelson E. C. R., Zwiker J.G. (2015). Diagnosis and management of develop- mental coordination disorder. Canadian Medical Association Journal. 187(9): 659-665

Henn, P. Maura, M., Carly, T., Niamh, MC., Róisín, R., Siobhán, O’S., \& Martina, C. (2003). Developmental coordination disorder (dcd). Dyspraxia/DCD Association, Cork in Co-operation with the DCD Unit St. Finbarrs Hospital. Retrieved from file: ///D: /jurnal\% 20 kuanti\%20yang\%20dipakai/17DCD_Prac tical_Tips.pdf.

Hurlock E. (2014). Perkembangan Anak - jil. 2 ed. 6. Bandung: Penerbit Erlangga. http://kin.perpusnas.go.id/DisplayData.a spx?pld $=23447 \& p$ RegionCode $=$ TELUNI $\underline{\& \text { Clienttdd }=116}$

Kaiser M.L. (2013). Children with Developmental Coordination Disorder: The Effects of Combined Intervention on Motor Coordination, Occupational Performance, and Quality of Life. Journal of Occupational Therapy, Schools, \& Early Intervention, 6:44-53, 2013

Kirby A., Sugden D.D. (2007). Children with Developmental Coordination Disorders. Journal the royal society of medicine. Volume 100. April 2007.

Kolb B., Harker A., Gibb R. (2017). Principles of plasticity in the developing brain. Journal Developmental medicine \& child neurology. 
PROFESI (Profesional Islam): Media Publikasi Penelitian 2019; Volume 16; No 2.

Website: ejournal.stikespku.ac.id

Missiuna, C., L, Rivard., \& N, Pollock. (2011). Children with developmental coordination disorder: at home, at school, and in the community. Can Child Centre for childhood Disability Research McMaster University School of Rehabilitation Science. Retrieved fromhttps: //www. canchild.ca/system/tenon/assets/attachme nts/000/000/195/original/developmental_ coordination_disorder_home_school_co mmunity_booklet.pdf.

Mufadhilah. (2014). Kegiatan Kolase Tiga Dimensi Terhadap Kemampuan Motorik Halus Anak. Jurnal mahasiswa.unesa. ac.id.index.php/jurnal-pendidikan.

Ofianti. (2011). Perbedaan Kemampuan Motorik Halus Anak Usia Prasekolah melalui Terapi Seni Rupa Kolase dan Clay di PG Islam Maryam Surabaya. Skripsi. Universitas Airlangga Press

Qian, Yu. (2014). Role of the dopamine system in motor skill learning: implications for neurodevelopmental disorders. Thesis. https://openarchive.ki.se/xmlui/handle/10 616/42062

Pawlak V., Jason N. D. (2008). Dopamine Receptor Activation Is Required for Corticostriatal Spike-Timing-Dependent Plasticity. The Journal of Neuroscience.

Rivilis et al. (2011).Cardiopulmonary fitness and endurance in children with deve- lopmental coordination disorder. Research in developmental disabilities. 31(2):345-9.

Ulrich, D. A. (2000). Test of gross motor development - 2. Retrieved from http:// 33202576.weebly.com/uploads/1/4/6/8/1 4680198/tgmd-2-2.pdf

Vareka L., Bruha P., Moucek R. (2017). Journal Giga Science. Oxford February 2017.

Wilson, B. N., \& S.G. Crawford. (2007). The developmental coordination disorder questionnaire 2007. Retrieved from http: //www. dedq. ca/ uploads/pdf/DCDQ Admin-Scoring-02-20-2012.pdf.

Wood G., Miles C.A.L., Coyles G., Alizadekhaiyat O., Vine S.J., Vicker J.N., Wilson M.R. (2017). A randomized control trial of a group-based gaze training intervention for children with Developmental Coordination Disorder. PLoS ONE 12(2):e0171782. Doi: 1371/journal.pone.0171782

Wuang Y.P., Su J.H., Su C.Y. (2012). Reliability and responsiveness of the Movement Assessment Battery for Children-Second Edition Test in children with developmental coordination disorder. Dev Med Child Neurol. 54(2):160-5. Doi: 10.1111/j.1469-8749.2011.04177.x 